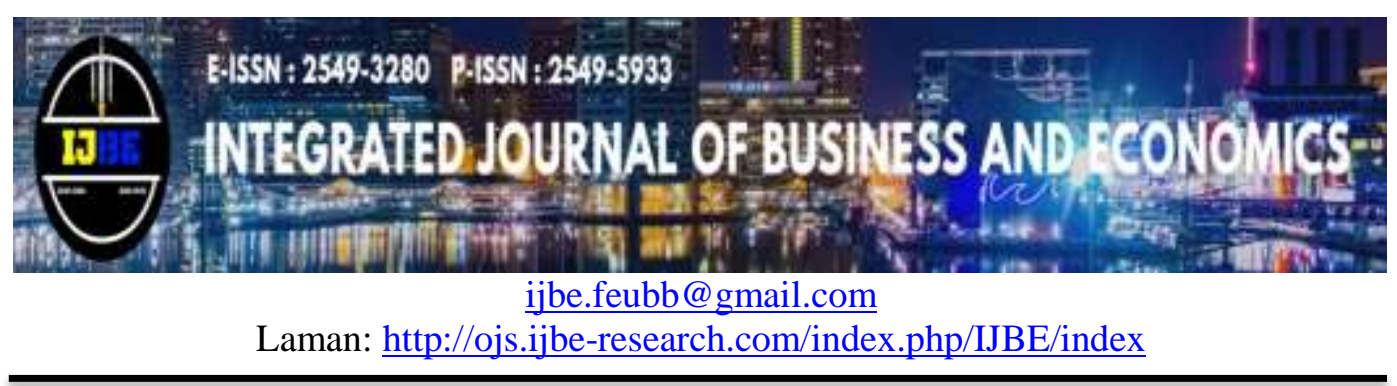

\title{
The Educators Personality Development in Industry 4.0 Based on Pumping HR-Model
}

\author{
Amir Tengku Ramly ${ }^{\mathrm{a}}$, Renea Shinta Aminda \\ ${ }^{a, b}$ Universitas Ibn Khaldun, Indonesia \\ amir.tengkuramly@uika-bogor.ac.id
}

\begin{abstract}
characteristics of Human personality that have existed since birth can be used as a basis for personal development and professionalism at work. Industrial Era 4.0 demands change in all fields, including the world of teaching. This study uses the literature review method by looking for various references critically to obtain valid and reliable data. The results of the analysis found that for the effectiveness of teaching in the classroom, educators must master and understand learning based on students' personalities and themselves. An understanding of the Personality Based Pumping-HR model can describe and map human personality in certain behaviours and characters. The results have a positive impact on the teaching process and teaching outcomes. Changes in the Personality of educators entering the digital era are very important when linked to the success of the teaching is carried out. So for effectiveness in teaching in the 4.0 era, an educator must understand the personality of students.
\end{abstract}

\section{Article Info}

- Received : January 22, 2020

- Revised : May 8, 2020

- Published: June 10, 2020

- No. Pages: 120 - 132

- DOI : 10.33019/ijbe.v4i2.261

- JEL : O15

- Keywords: Educators, Industrial 4.0, Personality, Pumping HR Model 


\section{Introduction}

Industry 4.0 or commonly called the digital era, is an era that is dominated by modern and sophisticated technology systems. This term includes the physicalcyber system, the internet and other media that affect human behaviour. Industry 4.0 produces "smart factories" (Hermann, 2016). In a modular, intelligent structure factory, cyber-physical systems monitor physical processes, create virtual copies of the physical world, and make decisions that are not centralized. Through the Internet for everything (IoT), the cyber-physical system communicates and cooperates and humans together. Through cloud computing, internal and cross-organization services are provided and utilized by various parties in the value chain.

According to Hermann (2016), there are four basic principles in Industry 4.0, namely: (1) Interoperability; the ability of machines, devices, sensors and people to connect and communicate with each other via the Internet for all (IoT) or the Internet for viewers (IoP), (2) Information transparency, (3) Technical assistance, and (4) Independent decision. If exceptions, distractions occur, or there are opposing goals, the job delegated to the employer. According to Klaus Schwab (2016):

"The Fourth Industrial Revolution, finally, will change not only what we do but also who we are. It will affect our identity and all the issues associated with it: our sense of privacy, our notions of ownership, our consumption patterns, the time we devote to work and leisure, and how we develop our careers, cultivate our skills, meet people, and nurture relationships. It is already changing our health and leading to a "quantified" self, and sooner than we think it may lead to human augmentation. The list is endless because it is bound only by our imagination".

The Fourth Industrial Revolution, in the end, will not only change what we do but also who we are. This will affect identity, privacy, ownership, consumption patterns, time to work and relax, and how we develop careers, develop skills, meet people, and build relationships. This changes our health and leads to a "quantified" self, and faster than we think can cause human augmentation. The list is endless because our imagination is limited.

The influence of era 4.0 will also spread to the world of teaching because the individuals involved in it directly or indirectly have become part of the changes in era 4.0. Therefore the role of educatorss as educators is increasingly needed by social abilities, personalities and the ability to understand students is increasingly important. According to Aslan (2011) teachers who teach with the basic belief that teaching from the heart rather than pursuing material will foster students with faith, knowledge, piety and character who are ready to face the challenges of education in the 21 st century. 
The results showed that understanding yourself and others (students) has an influence on a person's behaviour and performance (Ramly and Suherbi, 2020). With the teacher's understanding of personality (personality), self and students will have a positive impact on teaching in the classroom is expected to affect teaching motivation and the results of teaching and learning in the classroom. The development of the 4.0 era also requires different ways of thinking of teachers in seeing and treating their students (Ramly and Trisyulianti, 2006). Differences in learning behaviour, learning styles and learners' mindsets require educators to recognize them well. Educators' understanding of the personality of students will provide direct benefits to the teaching approach of an educator. The diversity of character of students can manage with an excellent technique, which is adapting to the personality of the students themselves.

The results of the study by Dianti, Syahid, Normawati (2019) found that the application of student learning models that pump with an understanding of student personality and learning styles has a direct influence on the effectiveness of teacher teaching, student learning processes and outcomes.Based on the above background, it can be formulated that the important problems for personality development of a educators welcoming the digital era are (1) Does human resources education need a change in thinking?, (2) Does HR educators need a teaching approach in the industrial era 4.0?, (3) How do personality development and teaching techniques fit into the Pumping-HR model? With the aim of (1) Introducing the importance of changing the personality of educatorss entering the digital era, (2) Introducing the concept of personal development and profession based on the Pumping-HR Model, and (3) As a scientific reference for universities for other research.

\section{Literature Review}

\section{Higher Education Human Resource Management}

According to Arwildayanto (2013) in general human resource management (HRM) of higher education institutions (PT) can be interpreted as a way for academicians to plan, organize, mobilize and assess human resources for higher education. They can contribute to the development and achievement of programs/visions and missions of higher education. There are eight important things for HR development in the 4.0 competition, namely: (1) Globalization, (2) Business Network \& HR Services Competition, (3) Creating Profits Through Growth and Cost Efficiency, (4) concentration on ability, (5) Change, Changes and changes, (6) Technology, (7) Resilience, Attractiveness, Measurement and Competence and Intellectual Capital, and (8) Change is not just Transformation (Suwatno \& Priansa, 2011).

Like companies, which always need educators who are not only competent but capable of making breakthrough ideas in the industrial era 4.0, universities are also able to produce competent, educated workers, with attitudes, mental and moral values that are good and able to adapt in competitive competition. According to Kindström (2010) the phenomenon of today, led to the emergence of new challenges and opportunities for companies to be able to understand and be 
competent in managing companies that are competitive (competitive advantage). Managing companies in the digital age require management knowledge that is not just knowledge but also involves art and good moral standards.

If management is defined as six important elements (6M), namely Men, money, Method, Material, Machine, and Market, so Men in the sense of assets and human resources will be an important part of the changes that occur. Men Management (HR) is management that functions to manage people (Men) in an organization so that the company is able to achieve its business goals that are sustainable and competitive. Related to this Arwildayanto (2013) argues that HR management in Higher Education in carrying out its functions needs to create a standard (Quality Management) of educators work, in order to be able to produce graduates that are in line with the needs of the digital era market. Quality standards can also function as a reference for improving the professionalism of educatorss. According to Wibowo (2013) related to this matter, there are 5 decisive factors, namely: (1) Professional Capability, (2) Professional Efforts, (3) Suitability of time used for professional activities, (4) Conformity between expertise and the field being managed and (5) adequate welfare.

\section{Industry 4.0}

The industrial revolution 4.0 is the fourth phase of the history of the industrial revolution, which began in the 18th century. Industry 4.0 was first introduced by Professor Klaus Schwab (2016), the world-famous economist from Germany, Founder of the World Economic Forum (WEF) who introduced the concept of the Industrial Revolution 4.0. Kravchenko \& Kyzymenko (2019), explains the 4.0 industrial revolution has fundamentally changed human life and work. Unlike the previous industrial revolution, the 4th generation industrial revolution has a wider scale, scope and complexity. Advances in industry 4.0 technology have influenced all fields involving various scientific disciplines. The fields that cause fundamental changes in Industry 4.0 include (1) artificial intelligence, (2) NanoTech, (3) biotechnology, and (4) Quantum Computer, (5) blockchain, (6) IT, and (7) ) three-dimensional printer.

According to Schwab (2016), the world underwent four industrial revolutions, namely (1) Industrial Revolution 1.0 in the form of the invention of a steam engine, railroad and sailing ship, (2) industrial revolution 2.0. in the form of the discovery of electrical energy which then led scientists to find other technologies such as lights, telegraph machines, and conveyor technology, (3) Revolution 3.0 occurred in the 20th century, has given birth to information technology and production processes that are controlled automatically. Industrial machines are no longer controlled by human labour but use Programmable Logic Controller (PLC) or computer-based automation systems, and (4) Industrial Revolution 4.0 has pushed the automation system in all activity processes. The increasingly massive internet technology has become the basis for online trade and transportation transactions, which has led to the emergence of online transportation businesses such as Gojek, Uber, Grab and other unicorns. Era 4.0 shows the integration of human activities with information technology and the economy is increasing. 


\section{Pumping HR Model}

Pumping HR Model is a learning concept that is used in HR training and development programs as a learning approach model. Pumping HR models are intellectual works that are produced through a 15-year HR development journey. The concept of learning pumping HR models is, as shown in Figure 1 below.

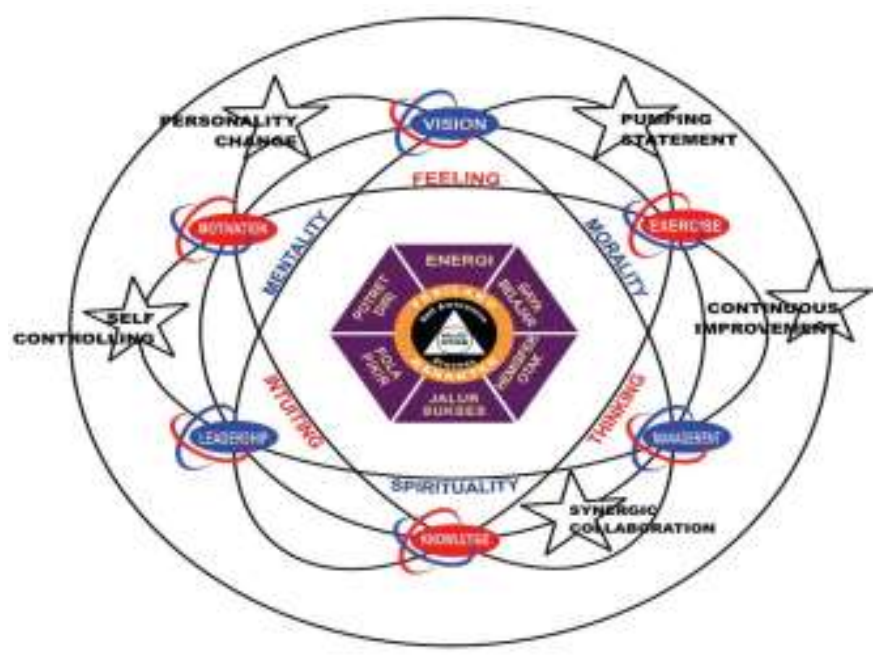

Figure 1. Concept of Learning Pumping HR Model (Ramly, 2019)

Pumping HR Model consists of 3 main foundations, namely pumping HR principle, Pumping HR Competency and Pumping HR Action. Pumping HR Model is supported by management theories and human behaviour such as (1) a good tree parable consisting of roots, stems and fruit/leaves (QS.14: 24), (2) relies on the principles of the milky way model ( solar system) which consists of the centre of the orbit, the orbital point and the orbital line (Gynanjar, 2006), (3) relies on Iceberg's theory which shows three human realms, namely the unconscious, the conscious and the conscious (Goodman, 2016), (4) relies on modern theories of human grace, namely the senses, intuition, and heart (Ramly, 2011).

\section{Personality}

In the concept of learning Pumping-HR model, personality is one of the Key Indicators (KI) of the Pumping Principle (the principle of success). According to Halpern (2015) personalities are a person's behaviour and success character. The behaviour of something that is easily seen and often changes, while the character of something that remains (genuine) in a person from birth. Characters that have appeared in a person are called behaviour. According Ramly \& Suherbi (2020), Personality is the way an individual reacts and interacts with other individuals. In this interaction, it involves elements of behaviour and related individual characters.

$$
\text { PERSONALITY }=\text { BEHAVIOR + CHARACTER }
$$


Periantalo \& Azwar (2017) explains that personality includes all thoughts, feelings and behaviour, awareness and unconsciousness. Personality guides people to adjust to the social and physical environment. Allport in Alwisol (2009) argues that personality is a dynamic organization of spiritual-physical (psychophysical) systems that determine its unique adaptation to its environment. According to Feeney \& Thrush (2010) personality refers to a person's general nature, thoughts, activities and feelings that influence systematically on his overall behaviour. Personality used to explain the individual nature that distinguishes it from others.

Personality is the behaviour that is shown by the social environment - the impression of the desired self that can be captured by the social environment (Gosling, Augustine, Vazire, S., Holtzman, \& Gaddis, 2011). When personality becomes a scientific term, its understanding develops to be more internal, something that is relatively permanent, guides, directs and organizes human activities. The diversity of definitions encapsulates understanding, models, integrative, substance and operational limits and distinguishes different concepts. Each personality expert gives their definition according to the paradigm they believe in and focuses on the analysis of the theory they develop. Personality is a dynamic arrangement that hidden within a person which is a system that will create a characteristic arrangement of behaviour, thoughts, and feelings of a person (Flood, 2010).

Personality also interpreted as a combination of a balance of physical and mental characteristics that give a person's identity (Wille \& DeFruyt, 2014). Personality is a unique and dynamic psycho-physical entity which contains habits and attitudes that are very useful in dealing with and adjusting the demands of one's life and life (Ramly \& Suherbi, 2020). Personality represents the characteristics of a person that noted for the constant arrangement of feelings, thoughts and behaviour. Personality is a very broad definition that will focus on many aspects of a person's differences. At the same time personality suggests that we follow a fixed set of behaviours and qualities that are hidden in a person (Linehan, 2018).

Personality is unique and consistent so that it can be used to distinguish between individuals with one another. Associated with differences in personality types, Jung classifies personality into two, namely extrovert and introvert personality types (Kurnia, 2012). Eysenck also distinguishes personality into two types, namely introverts and extroverts, where each of the patterns of actions possessed by introverted and extroverted personalities is different and contradictory (Suryabrata, 2015). Eysenck in Dominica (2018) said that extrovert and introvert personality types describe the uniqueness of individuals in behaving towards stimulus as an embodiment of the individual character, temperament, physical and intellectual in adjusting to their environment.

\section{Research Methods}

This study uses a literature review method by searching for various references critically to obtain valid and reliable data. The search for related literature carried out with a review of the results of research, scientific publications and books 
written by organizational management experts. According Wohlin (2014) The basic planning and motivation of a systematic literature study is independent of the search approach, which is the main concern here.

The literature review is a description of the theory, findings, and other research materials obtained from reference materials to be the basis of research activities to compile a clear frame of mind of the formulation of the problem to be examined (Kothari, 2004). A literature study is a mandatory activity in research, especially scientific research whose main purpose is to develop theoretical aspects as well as aspects of practical benefits. A literature study is carried out by each researcher with the main objective of finding a foundation to obtain and build a theoretical foundation, frame of mind, and determine provisional estimates or also called research hypotheses.

Researchers can organize, group and use various libraries according to their fields. Conducting a literature study can be done after they have determined the research topic and determined the formulation of the problem before the researcher goes into the field to collect the required data (Darmadi, 2011).

\section{Results}

\section{Development of Educators HR 4.0 Based on Personality Understanding,} Strengthening Competencies \& Spiritual Values

The development of HR educatorss in the 4.0 era began with the paradigm of the industry 4.0 era, which required HR to be able to adapt to changes in that era. The results of Ramly's research (2016), an organization that places human resources (HR) as organizational assets in a strategic position can be analogous to those who care for plants. On the other hand, organizations which position HR as workers can be analogous to wild plants. Plants, from the beginning deliberately planted, nurtured, fertilized and developed to the maximum with a variety of treatments to get plants that can produce something that is 'extraordinary'. In contrast, plants after growing are left and do not get maximum care.

From the opinions of the experts mentioned above, it can conclude that the organization that places its HR as a strategic asset is an organization that uses the principles of the human capital paradigm in the management of its employees. The fundamental paradigm in the development of educatorss in the 4.0 era was applying the human capital theory. Industrial Era 4.0 views humans as individual and organizational assets that have a significant impact on management practices themselves. Human capital is intangible assets in organizations. The human capital paradigm places humans as the primary foundation in supporting the organization's success in the future. Human capital is intangible resources provided by employees to the organization.

Human capital is a perspective that makes human factors an important element in an organization; This perspective represents the human factor in the organization, which is a combination of intellectuals, skills and expertise that forms the special 
character of the organization concerned. The human elements as organizational assets are those who want to learn, want to change, like to innovate, and always provide creative encouragement to the achievement of long-term goals. Although humans as an organizational asset that is not owned by the organization but obtained through the organization's work relationships with employees. Humans as organizational assets, will develop through development and training programs.

The training objective to make people an organizational asset (human capital) is to master the knowledge, skills and behaviours that emphasized in an organization's corporate culture. According to HRM experts to be able to offer a competitive advantage, training must involve a variety of human needs, more than just increasing skills (hard skills), but also behaviour, character and knowledge and other soft skills competencies (Noe, 2011).

HR development training based on understanding talents, strengthening competencies and spiritual values is a human capital strategy that is intangible assets, to prepare strategic assets that will be the foundation for developing HR in the long run, achieving competitive advantage. According to Poniman and Hadiyat (2015), the concept of competitive advantage is fundamentally shifting the focus of the strategy from tangible assets to intangible assets. The strategy of strengthening tangible assets such as factories and machinery will answer the comparative advantage. Still, the competitive advantage of a company to global competitiveness will be obtained through strengthening the intangible assets strategy of knowledge, information and technology.

\section{Talent Based HR Training}

The importance of the position of HR in an organizational structure must be balanced by the quality of HR itself, which is primarily determined by the development system developed in related organizations. HR expert theories such as Mc Clelland, Phillips, Armstrong, Baron, Zwell, Palan, Covey, Goleman, and Denah Zohar can conclude; HR development primarily determined by the talents, competencies and values of spirituality developed by the company.

People have innate abilities, behaviours, and personal energy and these elements make up the human capital they bring to their work. And it is they, not their employers, who own this capital and decide when, how and where they will contribute it. In other words, they can make choices. Work is a two-way exchange of value, not one-way exploitation of an asset by its owner.

Every human being has the innate talent, behaviour and energy. These three elements, according to Devenport in Prabowo, H. (2010), form human capital that will carry in the professional and everyday world. This also supported by the view of Barney (2010) that a company can obtain a competitive advantage that lasts longer if it has a pool of human resources that cannot be imitated or replaced by competitors. Competitive advantage is an advantage that comes from 
strengthening intangible assets, both human resources and management and technology.

The concept of HR training based on understanding talent is part of strengthening intangible assets, which reflected in the idea of TB-HRM (Talent Based Human Resources Management). TB-HRM focuses on developing human capital based on the principles of human capital through a talent management system (Fuad \& Ahmad, 2011). TB-HRM aims to optimize the employee development system through the preparation of talented human resources who have the competence and competence in carrying out their duties and responsibilities. Understanding, strengthening and talent management is becoming increasingly important for organizations that oriented to customer needs, service and superior competitiveness.

\section{Competency-Based Training}

The importance of competency factors in the development of human resources has emerged since 1973 through the work of Prof. David Mc Clelland in Rahardjo, Hasbullah \& Taqi (2019), titled "testing for competence Rather than Intelligence", which came to be known as CBHRM (competency-based human resource management). Competency-Based Human Resources Management (CBHRM) is a concept of learning in building a reliable human resource management system by utilizing competence as its central point. Competency-based HR development is the next strategic step in strengthening the organization's intangible assets. Talents without capability cannot be the driving force of an organization's progress. The right ability with the support of appropriate competencies will be the strength of individual competitive advantage that gives a significant influence on the development of the organization.

Training will be an effective means for companies to build and improve the competencies of their employees. Own competence to produce performance needs to done actions or work activities that focus on achieving the vision and goals of the organization. Wiek, Withycombe \& Redman (2011) offers six relevant competency groups that affect individual and organizational performance, namely: (1) management of actions, and specialist knowledge, (2) have basic competencies and advanced competencies. Basic competencies are essential characteristics such as the knowledge and skills that a person needs in achieving minimum standards of work. (3) Distinguishing competence refers to the factors of motives, personal characteristics, self-concept, and values that distinguish an employee who performs superior and ordinary employees. Excellent and practical competencies are competencies that improve employee performance. Basic competence gives employees the ability to be competent in their work so that work targets can be achieved, but to become superior performance and have competitive advantage requires unique competencies that are the result of the synergy of talents with essential competencies. 


\section{HR Training Based Values and Spirituality}

Regarding the values of spirituality in the development of human resources, it has been considered important by business people and HR experts in this decade of the 21st century. Zohar and Marshall argued that the values of spirituality are very important for businesses and organizations today because, with spirituality, the moral and social concerns of humans become greater and more qualified. With good morals and social care, humans find meaning, values, deepest goals and highest motivation in their work.

Spiritual values are the foundation for spiritual intelligence that is used to do a variety of goodness, truth, beauty, and compassion in our lives. The source of spiritual intelligence is a clean soul that is able to channel everything from the dimensions of imagination and psychology, which is deeper and richer into organizational life, daily life, family and institutions where humans are located. According to Zohar SQ is something we use to develop our abilities and longings for meaning, vision, and values.

The need for spiritual values is a human need facing a crisis of values and a capitalist system that can not be avoided in life, organizations and businesses that are being run. According to Suyono \& Mudjanarko (2017), the need for spiritual is the highest need possessed by someone, passing through 5 basic human needs that were popularized by Abraham Maslow. According to Van de Vliert (2013), that above the Maslow hierarchy needs, namely basic needs, a sense of security, being loved, valued, and actualization there are needs that are very basic and exceeds all the existing needs namely the needs of spiritual longing.

\section{Human Resources education in the 4.0 era requires a change in ways of Thinking and Approaches to Teaching}

Changes in technology in the 4.0 era affect changes in behaviour, social culture, including the way of thinking (mindset) of human resources (HR). Students who lived in the 4.0 era, also experienced changes in behaviour, work culture and ways of thinking in learning - planning for the future. Changes in the way of thinking of educatorss who incidentally are not a big generation in the 4.0 era needed in the context of adaptation in teaching. Teaching must always be up to date with the times. Because teaching is not only important for skill, but it will also provide a moral and mental foundation for students in facing changes and their future.

Changes in the way of thinking of educatorss require changes in teaching approaches. Changes in teaching approaches will determine changes in the behaviour of educatorss and students in the teaching and learning process. The approach provides a great opportunity for educatorss to develop students' knowledge, attitudes and skills that are appropriate to their time. 
Educators Competencies Through Understanding the Personality Based Pumping-HR model. The personality approach in the concept of learning Pumping HR is a teaching approach that explores the behaviour and character of educatorss and students. Behaviour is something that can be used by educatorss in classroom control. Sanguinis behaviour requires an approach through teaching as a pleasure for educatorss and students. Cholesterol behaviour requires an approach through teaching that impresses students in strategic and proud positions. Phlegmatic behaviour requires a teaching approach that is not complicated and is repeated. Melancholy behaviour requires systematic, orderly and classy teaching.

Educatorss also need a teaching approach through character understanding as a way of understanding students' mindset preferences. There are 4 main preferences in the mindset of students, namely (1) sensing, (2) intuition, (3) thinking, and (4) feeling. The mindset with sensing preference shows the figure of a student who has a mindset with a dose of information that is seen, felt, heard, smelled and felt. Intuiting mindset requires an approach based on intuition to convey something behind an event. Thinking mindset requires a logical approach, and feeling mindset requires a backrest of values and subjectivity of students themselves.

\section{Conclusion and Suggestion}

Human resource educators (HR) need a change in ways of thinking in the world of teaching in the 4.0 era. The way of thinking of teaching must change to the way of thinking of learning. Therefore HR educators need different teaching approaches tailored to the personality of students. Related to concept-based learning and the development of the Pumping-HR model, it takes the development of HR personality educators in individual capacities, professions, and teaching technical skills.

In the capacity of the individual teacher must have a strong belief (belief system) in himself and his future, understand his personality, and have values (values) as a teacher. In the Profession, the teacher has a good teaching paradigm by mastering 4 quadrants of teachers. Technically the teacher must have the skills to understand learners' behaviour and learning styles. make its mapping, and teach based on students' personality..

Changes in the Personality of HR educators entering the digital era are very important when linked to the success of the teaching is carried out. The concept of personal development and profession based on the Pumping HR Model is a teaching approach by understanding student behaviour and character. It recommended that educatorss understand the personality of themselves and students and use personality types in the teaching process. 


\section{Acknowledgement}

I would like to thank the educatorss at Ibn Khaldun University, the UIKA Bogor human resource study centre team and the IPB University human resource development centre for their support and permission to conduct a personalitybased Pumping HR Model workshop.

\section{References}

1. Aslan. (2017). Pumping Teacher dalam Tantangan Pendidikan Abad 21. Jurnal Muallimuna, 2(2), 89-100.

2. Arwildayanto. (2013). Manajemen Sumber Daya Manusia Perguruan Tinggi, Pendekatan Budaya Kerja Dosen Profesional. Bandung: Alfabeta.

3. Barney, Jay. B. (2010). Gaining and Sustaining Competitive Advantage 4th Edition, USA: Addison-Wesley Publishing Company.

4. Dianti, M., Syahid, A., \& Normawati, N. (2019). Penerapan Model Pembelajaran Pumping Student Dalam Meningkatkan Hasil Belajar Pada Mata Pelajaran Pendidikan Agama Islam Di Sekolah Menengah Pertama Negeri 4 Kasimbar. Jurnal Kolaboratif Sains, 1(1).

5. Feeney, B. C., \& Thrush, R. L. (2010). Relationship influences on exploration in adulthood: the characteristics and function of a secure base. Journal of personality and social psychology, 98(1), 57.

6. Flood, R. L. (2010). The relationship of 'systems thinking'to action research. Systemic Practice and Action Research, 23(4), 269-284.

7. Gosling, S. D., Augustine, A. A., Vazire, S., Holtzman, N., \& Gaddis, S. (2011). Manifestations of personality in online social networks: Self-reported Facebookrelated behaviors and observable profile information. Cyberpsychology, Behavior, and Social Networking, 14(9), 483-488.

8. Halpern, D. (2015). Inside the nudge unit: How small changes can make a big difference. Random House.

9. Hermann, Pentek, Otto. (2016). Design Principles for Industrie 4.0 Scenarios, diakses dari: https://id.wikipedia.org/wiki/Industri_4.0 pada tanggal 8 Agustus 2019.

10. Kindström, D. (2010). Towards a service-based business model-Key aspects for future competitive advantage. European management journal, 28(6), 479-490.

11. Kurnia, S. I. (2012). Hubungan antara tipe kepribadian (ekstrovert dan introvert) dengan kebermaknaan hidup (meaning of life) pada mahasiswa Fakultas Psikologi UIN Maulana Malik Ibrahim Malang (Doctoral dissertation, Universitas Islam Negeri Maulana Malik Ibrahim).

12. Kothari, C. R. (2004). Research methodology: Methods and techniques. New Age International.

13. Kravchenko, A., \& Kyzymenko, I. (2019). The Forth Industrial Revolution: new paradigm of society development or posthumanist Manifesto. Philosophy \& cosmology, (22), 120-128.

14. Linehan, M. M. (2018). Cognitive-behavioral treatment of borderline personality disorder. Guilford Publications.

15. Periantalo, J., \& Azwar, S. (2017). Pengembangan skala kepribadian siswa SMA dari tipologi kepribadian Jung dan Myers-Briggs. Jurnal Sains Sosio Humaniora, 1(2), 191-207.

16. Prabowo, H. (2010). Knowledge Management di Perguruan Tinggi. Binus Business Review, 1(2), 407-415.

17. Rahardjo, B., Hasbullah, R., \& Taqi, F. M. (2019). Coffee Shop Business Model Analysis. Integrated Journal of Business and Economics, 3(2), 140-152. 
18. Ramly, A. T., \& Trisyulianti, E. (2006). Pumping Teacher: Memompa Teknik Pengajaran Menjadi Guru Kaya. Kawan Pustaka, Jakarta.

19. Ramly, A. T. (2019). Evaluation of Pumping HR (Human Resources) Model-Based Training Program on Human Resources Development at Bogor Agricultural University (IPB). Integrated Journal of Business and Economics, 3(2), 153-163.

20. Ramly, A. T. (2016). Pengembangan Sumber Daya Manusia yang Unggul Berbasis Pumping-HR Model. Jurnal Manajemen, 7(2), 138-151.

21. Ramly, A. T., \& Suherbi, D. (2020). Personality Type Based Pumping-HR Model Toward Working Targets of The Civil Service. Jurnal Manajemen, 24(1), 109-123.

22. Suyono, J., \& Mudjanarko, S. (2017). Motivation Engineering to Employee by Employees Abraham Maslow Theory. Journal of Education, Teaching and Learning, 2(1), 27-33.

23. Schwab, Klaus. (2016). The Fourth Industrial Revolution What it Means and How to Respond. Diakses dari: https://www.weforum.org/agenda/2016/01/the-fourthindustrial-revolution-what-it-means-and-how-to-respond/ pada tanggal 5 Januari 2019.

24. Van de Vliert, E. (2013). Climato-economic habitats support patterns of human needs, stresses, and freedoms. Behavioral and Brain Sciences, 36(5), 465-480.

25. Wille, B., \& De Fruyt, F. (2014). Vocations as a source of identity: Reciprocal relations between Big Five personality traits and RIASEC characteristics over 15 years. Journal of Applied Psychology, 99(2), 262.

26. Wiek, A., Withycombe, L., \& Redman, C. L. (2011). Key competencies in sustainability: a reference framework for academic program development. Sustainability science, 6(2), 203-218.

27. Wohlin, C. (2014, May). Guidelines for snowballing in systematic literature studies and a replication in software engineering. In Proceedings of the 18th international conference on evaluation and assessment in software engineering (pp. 1-10). 